\title{
P2X3-Containing Receptors as Targets for the Treatment of Chronic Pain
}

\author{
Jeffrey L. Krajewski ${ }^{1}$ \\ Accepted: 17 September 2020 / Published online: 2 October 2020 \\ (C) The American Society for Experimental NeuroTherapeutics, Inc. 2020
}

\begin{abstract}
Current therapies for the treatment of chronic pain provide inadequate relief for millions of suffering patients, demonstrating the need for better therapies that will treat pain effectively and improve the quality of patient's lives. Better understanding of the mechanisms that mediate chronic pain is critical for developing drugs with improved clinical outcomes. Adenosine triphosphate (ATP) is a key modulator in nociceptive pathways. Release of ATP from injured tissue or sympathetic efferents has sensitizing effects on sensory neurons in the periphery, and presynaptic vesicular release of ATP from the central terminals can increase glutamate release thereby potentiating downstream central sensitization mechanisms, a condition thought to underlie many chronic pain conditions. The purinergic receptors on sensory nerves primarily responsible for ATP signaling are P2X3 and $\mathrm{P} 2 \mathrm{X} 2 / 3$. Selective knockdown experiments, or inhibition with small molecules, demonstrate P2X3-containing receptors are key targets to modulate nociceptive signals. Preclinical studies have identified that P2X3-containing receptors are critical for sensory transduction for bladder function, and clinical studies have shown promise in treatment for bladder pain and pain associated with osteoarthritis. Further clinical characterization of antagonists to P2X3-containing receptors may lead to improved therapies in the treatment of chronic pain.
\end{abstract}

Key Words $\mathrm{P} 2 \mathrm{X} 3 \cdot \mathrm{ATP} \cdot$ nociception $\cdot$ sensitization $\cdot$ pain $\cdot$ hyperalgesia

\section{Introduction}

Pain is one of the most common reasons for patients to seek medical attention and is a major burden on the quality of life for those who suffer and their caregivers. Chronic pain, defined as pain that lasts or recurs for more than 3 to 6 months [1], is estimated to affect up to 116 million adults in the USA alone with hundreds of millions of dollars in lost productivity annually [2]. While nociceptive pain, also known as "protective pain," is important for survival, many forms of chronic pain linger long after a healed injury and do not appear to serve any useful purpose [3]. Current therapies used to treat chronic pain are woefully inadequate with many dose-limiting side effects. The difficulty in getting effective treatment for

Electronic supplementary material The online version of this article (https://doi.org/10.1007/s13311-020-00934-2) contains supplementary material, which is available to authorized users.

Jeffrey L. Krajewski

jeffrey.krajewski@merck.com

1 Neuroscience Department, Merck \& Co., Inc., West Point, PA, USA chronic pain is thought to be a key factor in many patients also developing severe psychiatric comorbidities, with $45 \%$ suffering from major depressive disorder (MDD) as opposed to 5\% in the general population [4]. Increased understanding of the mechanisms that underlie chronic pain is needed to develop new therapies with improved clinical outcomes.

Adenosine triphosphate (ATP) is well known as the principal source of energy for cellular metabolism, but it was first postulated in 1953 that ATP can also serve to modulate neurotransmission. In a rabbit ear preparation, exogenously applied ATP caused antidromic vasodilation that was reduced with the co-application of a cholinesterase inhibitor [5], although at the time the receptors responsible for this effect were not known. The advent of molecular cloning and heterologous expression systems allowed researchers to fully characterize what is now known as the purinergic receptor family. Receptors that activate when exposed to ATP are called P2 receptors and can exist as ligand-gated ion channels (P2X1$\mathrm{P} 2 \mathrm{X} 7)[6,7]$ and $\mathrm{G}$ protein-coupled receptors (P2Y1, P2Y2, P2Y4, P2Y6, P2Y11-P2Y14). Adenosine-responding receptors, originally classified as $\mathrm{P} 1$ receptors, are now called $\mathrm{A} 1$, $\mathrm{A} 22_{\mathrm{A}}, \mathrm{A} 2_{\mathrm{B}}$, and $\mathrm{A} 3$. The nomenclature and pharmacology of 
$\mathrm{P} 2 \mathrm{Y}$ and $\mathrm{A} 1-\mathrm{A} 3$ receptors are covered in several excellent reviews [8-13] and therefore will not be a focus here.

P2X receptor subunits form trimeric transmembrane complexes consisting of homomeric and heteromeric ionotropic receptors [7, 14]. Receptors that contain a P2X3 subunit ( $\mathrm{P} 2 \mathrm{X} 3$ homomers and/or P2X2/3 heteromers) will be referred to as $\mathrm{P} 2 \mathrm{X} 3$-containing receptors. Confirmation of the formation of the P $2 \times 2 / 3$ heteromer was verified by coimmunoprecipitation experiments and patch-clamp electrophysiology which possessed properties that match ATPgenerated currents in neurons $[15,16]$. The exact stoichiometry of the $\mathrm{P} 2 \mathrm{X} 2 / 3$ heteromer in native tissue remains to be determined [17]. Experiments with heterologously expressed rP2X2 receptor showed ATP-induced currents exhibited strong cooperativity with a $\mathrm{n}_{\mathrm{H}}$ approximately 2 , suggesting that more than one ATP molecule must bind before the channel opens [18]. Recent structural data of the human P2X3 receptor reveal the key protein movements that occur upon the binding of ATP to induce a conformational change which leads to the opening of the ion pore [19]. When exposed to ATP, P2X receptors open within milliseconds and are nonselective cation channels, with significant permeability to calcium [20]. Ion channel current properties (e.g., rate of inactivation, tachyphylaxis) and pharmacology can vary dramatically between P2X channels formed by different subunit combinations $[6,7,20,21]$.

P2X3 subunits are primarily expressed in peripheral nerves that innervate a variety of tissues important for nociception [22-26], chemosensation [27], and tissue function such as sensing the stretching of hollow organs (e.g., bladder) [28, 29]. Antagonists selective for $P 2 X 3$-containing receptors (homomeric or heteromeric) have demonstrated efficacy in a wide range of preclinical models of micturition disorders [30-33], pulmonary hypertension [27], and cough [34, 35], while selective antagonists to $\mathrm{P} 2 \mathrm{X} 3$-containing receptors have demonstrated clinical efficacy in chronic refractory cough [36-38]. A common feature of all these symptoms is a key role for extracellular ATP that sensitizes sensory nerve endings thereby driving a hyperexcitable state, primarily acting through P2X3-containing receptors. This review will summarize the importance of ATP as a modulator of nociception, the preclinical evidence for a role of $\mathrm{P} 2 \mathrm{X} 3$-containing receptors in pain signaling, and the potential for clinical development of antagonists selective for $\mathrm{P} 2 \mathrm{X} 3$-containing receptors as a novel mechanism for treating chronic pain.

\section{ATP as a Modulator of Nociceptive Signaling}

The critical role for ATP as a sensory signaling neurotransmitter has been studied for over 50 years [39]. Evidence pointing to a nociceptive role for ATP first came from clinical studies where administration caused a painful reaction when injected into a blister base [40] or when intracutaneously injected into normal skin [41]. Hamilton et al. demonstrated that iontophoretic application of ATP to the skin of human volunteers caused a dose-dependent increase in pain similar to a burning and stinging sensation [42]. Importantly, when applied acutely, ATP induced depolarizing currents in dissociated sensory neurons isolated from dorsal root ganglia (DRG) [24, 43-45] and nodose ganglia [46-48], suggesting purinergic receptors expressed in nociceptors might be mediating the observed clinical effects.

Exogenously applied ATP is readily hydrolyzed in vivo into ADP, which is then further metabolized to adenosine, both of which are both bioactive and their downstream activities could confound interpretation of the effects ascribed to ATP $[8,9,11,13]$. The ATP analog $\alpha, \beta$-methylene ATP $(\alpha, \beta$-MeATP) is more resistant to hydrolysis making it an ideal tool to study the role of $\mathrm{P} 2 \mathrm{X}$ receptors in vivo. In rats, intraplantar administration of $\alpha, \beta$-MeATP causes nocifensive behavior in a dose-dependent manner [49]. The flinching behavior can be prevented by desensitization via 30 -min local pretreatment with $\alpha, \beta$-MeATP, whereas pretreatment with $\alpha, \beta$-MeATP does not influence nocifensive behavior caused by intraplantar injection of bradykinin $(1 \mathrm{nmol})$ or formalin $(0.5 \%, 0.1 \mathrm{ml})$. Interestingly, local pretreatment of the TRPV1 agonist capsaicin (100 micrograms) abolished nocifensive behavior caused by $\alpha, \beta$-MeATP, bradykinin, and formalin, indicating that receptors for each of these ligands are colocalized with TRPV1 on sensory fibers [49]. Similar findings have been observed in human psychophysical studies, where transcutaneous iontophoresis of ATP produced an increase in pain reporting and prior desensitization of skin with capsaicin abolished the ATP-induced pain responses [42]. Direct evaluation of the effects of ATP analogs on nociceptor subtypes can be done using an ex vivo skin-nerve prep in rodents or microneurography in humans, which allows classification of sensory fiber types based on conduction velocity and responses to thermal and mechanical stimuli. In naïve rodent skin, application of $\alpha, \beta$-MeATP to sensory nerve endings generated an increase in activity in about $40 \%$ of the nociceptive units, with $75 \%$ of those responders identified as Cmechanical and heat sensitive (CMH or polymodal nociceptors), and the remaining being Cmechanonociceptors (CMs) [50]. Microneurography studies in human volunteers demonstrate $64 \%$ of $\mathrm{CM}$ fibers and $63 \% \mathrm{C}$-mechanoinsensitive fibers $\left(\mathrm{CM}_{\mathrm{i}}\right)$ respond to acute ATP injection. Thermal responses of the $\mathrm{CM}_{\mathrm{i}}$ fibers allow further classification as mechanoinsensitive, heat responsive (CH 9/11 units) and mechanoinsensitive, heat insensitive $\left(\mathrm{CM}_{\mathrm{i}} \mathrm{H}_{\mathrm{i}}\right.$ 5/11 units) [51]. Collectively, these studies demonstrate that ATP, or ATP analogs, can elicit a painful response through direct excitation of nociceptive fibers.

Further experimentation with local application of $\alpha, \beta$ MeATP showed a potentiation of nocifensive behavior under 
conditions where the tissue is injured or inflamed. The concentration threshold to detect a behavioral response to intraplantar $\alpha, \beta$-MeATP shifted 100 -fold lower in skin pretreated with dilute carrageenan solution compared to normal skin [52]. Additionally, intraplantar co-administration of $\alpha, \beta$-MeATP with PGE2 generated a nocifensive response greater than that observed with administration of each agent alone, indicating a synergistic relationship exists between peripheral purinergic and prostaglandin nociceptive signaling [52]. Co-administration of $\alpha, \beta$-MeATP with a low dose of formalin dose-dependently enhanced the phase 2 response (12-60 min after application) but not phase 1 (0-10 min) implying an enhancement of mechanisms that lead to central sensitization [53]. In skin previously sensitized with carrageenan, activity in C-MH fibers were potentiated with $\alpha, \beta$ MeATP at a much lower concentration compared to naïve skin, which temporally correlated with nociceptive behavior in conscious rats highlighting a link between neuronal hyperexcitability and pain-related behavior [50, 52]. A similar increase in $\alpha, \beta$-MeATP-induced sensitivity was observed in rat skin pretreated with Complete Freund's Adjuvant (CFA) [54]. In healthy volunteers whose skin was sensitized with capsaicin or UVb irradiation, ATP-induced pain behavior was significantly enhanced compared to naïve skin [42]. Interestingly, ATP alone is not sufficient to sensitize Cnociceptors to thermal or mechanical stimuli [51], suggesting that a co-factor which is released only under sensitized or inflamed conditions may be needed to potentiate the signaling of ATP in sensory fibers. Collectively, these studies demonstrate that ATP, or ATP analogs, can elicit painful responses through direct excitation of nociceptive fibers and potentiate activity in these fibers under inflamed or sensitized conditions, and that many of these findings are translatable to humans.

\section{Expression and Function of P2X3-Containing Receptors in Nociceptive Pathways}

Considerable heterogeneity can be observed in ATPgenerated currents in sensory neurons, which can consist of rapidly inactivating currents with pronounced tachyphylaxis or those with more sustained current kinetics that do not exhibit tachyphylaxis $[24,29,44,45,56]$. The percentage of acutely isolated sensory neurons that generate ATP-sensitive currents range from 40 to $95 \%$, with the differences likely due to the species tested and neuronal culture conditions [24, 43-45]. Messenger-RNA localization and immunohistochemical studies demonstrate that many sensory neurons express both $\mathrm{P} 2 \mathrm{X} 2$ and $\mathrm{P} 2 \mathrm{X} 3$ subunits $[45,57,58]$ in addition to $\mathrm{P} 2 \mathrm{X} 1[56,59]$; however, see [60]. Heterologous expression of P2X3 [61] and electrophysiology studies in neurons from $\mathrm{P} 2 \mathrm{X}^{-1-}$ animals $[28,29,62]$ have identified the P2X3 homomer as responsible for the rapid transient currents in
DRG, while co-expression of $\mathrm{P} 2 \mathrm{X} 2$ with $\mathrm{P} 2 \mathrm{X} 3$ can produce heteromers $[15,16,63]$ and yield currents with significantly slower inactivation kinetics that resemble the sustained currents seen in DRG and nodose neurons [15, 58]. Expression of $\mathrm{P} 2 \mathrm{X} 3$ is enriched in small diameter nociceptors that coexpress isolectin B4 (IB4) and glial-derived neurotrophic factor (GDNF), indicating these neurons are non-peptidergic, as well as in a subpopulation of A $\delta$-fibers [24, 45, 64, 65]. In mouse sensory neurons, $\mathrm{P} 2 \mathrm{X} 3$ is also co-expressed with MrgprD, which are classified as nociceptors due to the presence of TTX-resistant $\mathrm{Na}^{+}$currents and $\mathrm{Ca}^{2+}$ currents that are inhibited by $\mu$-opioids $[66,67]$. P2X3 subunits can also form a cognate receptor with other structurally related Cys-loop receptors. Heterologous co-expression of P2X3 with ASIC3, an important receptor for pain signaling in its own right $[68,69]$, demonstrates cross-functional regulation of receptor activity in a calcium-dependent manner [70]. P2X3 and ASIC3 can be coimmunoprecipitated from rat DRG membranes demonstrating a close spatial association. In vivo studies demonstrate a facilitation of $\alpha, \beta$-MeATP-mediated nocifensive behavior with low $\mathrm{pH}$, an activator of ASIC3 receptors, when coadministered intraplantar. Collectively, these data suggest the P2X3/ASIC3 cognate receptor may be important for acidic and purinergic-mediated nociceptive signaling in the periphery [70]. P2X3 is also often co-expressed with the nociceptive marker TRPV1 [22-26]. The axons of TRPV1 ${ }^{+} / \mathrm{ATP}^{-}$-sensitive neurons project and terminate in lamina $\mathrm{II}_{\text {inner }}$ in the dorsal horn with P2X3 immunoreactivity concentrated in the central terminals $[28,57,71-73]$. Other neurons that are TRPV1 ${ }^{-} / \mathrm{ATP}$-sensitive project deeper into lamina $\mathrm{V}$, indicating distinct purinergic pathways exist with divergent sensory signaling $[25,74]$. Peripherally, $\mathrm{P} 2 \mathrm{X} 3$ is expressed in sensory nerve terminals found in several tissues, including skin and hollow organs in the viscera such as bladder and endometrium tissue $[57,71,75,76]$. The proposed mechanism of peripheral and presynaptic $\mathrm{P} 2 \mathrm{X} 3$-containing receptors in modulating nociceptive behavior will be a subject of further discussion later in this review (see "Site of Action of P2X3-Containing Receptor Modulation of Nociceptive Signaling").

It is important to note that the expression profile of $\mathrm{P} 2 \mathrm{X} 3$ and $\mathrm{P} 2 \mathrm{X} 2 / 3$ in sensory neurons has important differences when comparing preclinical species and primates. While $\mathrm{P} 2 \mathrm{X} 3$ homomers and $\mathrm{P} 2 \mathrm{X} 2 / 3$ heteromers are both widely expressed in rodent sensory neurons [24, 29, 44, 45, 56-58], neurons isolated form non-human primate and human DRG show robust $\mathrm{P} 2 \mathrm{X} 3$-subunit expression with undetectable $\mathrm{P} 2 \mathrm{X} 2$-subunit expression as determined with reverse transcriptase PCR (RT-PCR) and immunohistochemistry (IHC) [77]. This expression profile was confirmed using electrophysiology in non-human primate DRGs where 256/256 neurons have a transient $\alpha, \beta$-MeATP-induced current and zero neurons have slowly desensitizing currents consistent with a lack of P2X2/3 receptors [77]. These findings may impact the 
translation of preclinical findings to clinical efficacy, particularly when interrogating nociceptive mechanisms driven primarily through $\mathrm{P} 2 \mathrm{X} 2 / 3$ heteromers.

\section{Preclinical Evidence Suggesting Therapeutic Utility of P2X3 Receptor Antagonists for Chronic Pain}

Several lines of evidence point to $\mathrm{P} 2 \mathrm{X} 3$-containing receptors as an attractive target for the treatment of some types of chronic pain: (a) elevated levels of the P2X agonist ATP are found in injured or inflamed tissue [78-80], (b) P2X3 subunits are expressed in sensory neurons in both preclinical and clinical tissue $[57,72,77]$, (c) P2X3 expression in neurons demonstrate plasticity ipsilateral to the site of nerve injury $[71,81$, 82] and inflammation [83, 84], and, finally, (d) P2X3containing receptor agonists directly activate sensory Cfibers and cause nocifensive behavior in both preclinical and clinical studies [42, 50, 51].

Previous efforts to study P2X3-containing receptors and the role they play in sensory transduction in vivo were hampered by the lack of selective ligands (see Table 1) and reviewed in $[21,85,86]$.

One of the first non-nucleotide P2X ligands with potent and selective inhibition of P2X3-containing channels was 5-[[[(3-phenoxyphenyl)methyl][(1S)-1,2,3,4-tetrahydro-1naphthalenyl]amino]carbonyl]-1,2,4-benzenetricarboxylic acid (A-317491), a selective P2X3-containing receptor antagonist with $>100$-fold selectivity over other $\mathrm{P} 2$ receptors and non-purinergic receptors [87]. When dosed systemically, A317491 was efficacious in the CFA model of inflammatory pain (thermal hyperalgesia and allodynia endpoints), as well as in the chronic constriction injury (CCI) model of nerve injury (thermal hyperalgesia and allodynia). The in vivo efficacy of A-317491 was likely due to its activity on P2X3containing receptors since an equivalent dose of the (R)-enantiomer A-317344, which is significantly less active against $\mathrm{P} 2 \mathrm{X} 3$-containing receptors in vitro, was ineffective in reversing hyperalgesia in these models [87]. Interestingly, A317491 was inactive in models of acute nociception with noxious stimuli, including thermal, mechanical, and intraplantar capsaicin. These data support earlier observations of enhanced responsiveness to sensory ATP signaling only under conditions where the tissue is previously sensitized or injured [42, 51, 52]. More recently, structurally distinct antagonists of P2X3-containing receptors have demonstrated efficacy in preclinical models of pain. Gefapixant (AF-219/MK7264), a selective P2X3-containing receptor antagonist [89], was examined in two models of inflammation: CFA and mono-iodoacetate-induced experimental osteoarthritis model of the knee. Gefapixant showed robust reversal of hypersensitivity when dosed orally at $30 \mathrm{mpk}$ with paw withdrawal threshold (Von Frey) and weight-bearing endpoints with efficacy similar to naproxen in both models. In the spared nerve injury (SNI) model of neuropathic pain, $30 \mathrm{mpk}$ p.o. gefapixant fully reversed mechanical hyperalgesia (Von Frey) and weight-bearing endpoints with efficacy equivalent to that of gabapentin [89]. Finally, two representative compounds from a structurally distinct series of selective P2X3containing antagonists, MK-3901 [92], and MK-2548 [93], demonstrated efficacy when dosed systemically in preclinical chronic models of pain. Selective P2X3-containing receptor antagonists have also been evaluated in preclinical models of cancer pain. Chronic pain in patients suffering from bone cancer is one of the most commonly reported maladies and is also one of the most difficult to manage [94, 95]. Evidence exists that $\mathrm{P} 2 \mathrm{X} 3$ expression is upregulated on nerve fibers in preclinical models of bone cancer pain [96, 97]. In a mouse tumor model, the concentration of extracellular ATP increased from undetectable levels in tumor-free tissue to several hundred micromolar in the tumor interstitium [98], which is high enough to directly activate P2X3-containing receptors [20]. AF-353 (formally RO-4), a potent and selective antagonist of P2X3-containing receptors [99], was tested in a model of bone cancer pain established by the introduction of MRMT-1 mammary gland carcinoma cells onto the tibia of rats, a model that generates an increase in tactile hypersensitivity approximately 10 days after implantation [100]. When dosed prophylactically, AF-353 prevented the development of tactile hypersensitivity and deficits in weight-bearing, although this did not translate to improvements in bone density [101]. In another
Table 1 P2X3-containing receptor antagonists

\begin{tabular}{llll}
\hline Compound name & ${\mathrm{P} 2 X 3 \mathrm{IC}_{50}(\mathrm{nM})}$ & ${\mathrm{P} 2 X 2 / 3 \mathrm{IC}_{50}(\mathrm{nM})}$ & Reference \\
\hline A-317491 & 100 & 100 & {$[87]$} \\
AF-353 (RO-4) & 10 & 80 & {$[88]$} \\
AF-792 (compound 28, RO-5) & 6 & 13 & {$[88]$} \\
Gefapixant (AF-219/MK-7264) & 150 & 220 & {$[89]$} \\
Compound 15 h & 280 & $>2500$ & {$[90]$} \\
TNP-ATP & 1 & 7 & {$[21]$} \\
PPADS & 1000 & 1000 & {$[91]$} \\
\hline
\end{tabular}


paradigm, AF-353 significantly reversed tactile hypersensitivity when dosed at day 17 (peak-onset); however, weightbearing was unaffected. Mechanical stimulation of MRMT-1 cells in vitro leads to a 5-fold increase in ATP release; however, this was not affected with the co-incubation of $25 \mu \mathrm{M}$ AF-353 demonstrating the behavioral effects of AF-353 are not due to changes in ATP release [101]. In a similar model of cancer pain, A-317491 dose-dependently suppressed thermal hyperalgesia produced by the intratibial inoculation of NCTC 2472 fibrosarcoma cells to $\mathrm{C} 3 \mathrm{H} / \mathrm{HeJ}$ mice [102]. However, when $4 \mathrm{~T} 1$ mammary carcinoma cells were co-inoculated with NCTC 2472 fibrosarcoma cells, A-317491 did not demonstrate a robust effect, indicating that pain signaling induced only by specific tumor cell types may be sensitive to P2X3containing receptor antagonists [103]. Large molecule antagonists to P2X3-containing receptors have also been identified. The monoclonal antibody 12D4, directed to the P2X3-subunit, exhibits potent inhibition of $\mathrm{P} 2 \mathrm{X} 3$ currents evoked by $\alpha, \beta$-MeATP in $1321 \mathrm{~N} 1$ cells and in acutely dissociated rat DRG neurons [104]. Short-term exposure of cells expressing P2X2/3 show a potentiation of $\alpha, \beta$-MeATP currents; however, longer exposures inhibit these currents. Interestingly, 12D4 appears to bind to the desensitized state of P2X3-containing receptors, and prolonged incubations drive membrane internalization leading to a decrease in current density [104]. In vivo studies with 12D4 dosed 3 days prior to balloon distention demonstrate efficacy in the TNBS-induced colitis visceral pain model, although 12D4 was inactive in the formalin model and in CFA with a thermal withdrawal endpoint with the same dosing regimen [104]. Post hoc confirmation of successful P2X3-receptor internalization on DRG neurons was not presented in these in vivo studies; therefore, a potential explanation for the limited efficacy profile is an insufficient reduction in $\mathrm{P} 2 \mathrm{X} 3$ surface expression with systemic dosing.

Further evidence supporting the role of $\mathrm{P} 2 \mathrm{X} 3$-containing receptors in nociceptive signaling comes from selective knockdown of $\mathrm{P} 2 \mathrm{X} 3$ and $\mathrm{P} 2 \mathrm{X} 2$ subunits. Cockayne et al. confirmed selective knockdown of P2X3 by the absence of all transient ATP and $\alpha, \beta$-MeATP-induced currents in both DRG and nodose ganglia and the elimination of P2X3 immunoreactivity in DRG and the central terminals of the spinal cord $[28,29]$. These $\mathrm{P} 2 \mathrm{X}^{--}$mice had a reduced response to intraplantar flinching in response to $\alpha, \beta$-MeATP [28], and in both acute and persistent phases of the formalin model $[28,62]$. Consistent with what has been observed with pharmacological tools, $\mathrm{P} 2 \mathrm{X}^{-/-}$mice had normal responses to acute noxious stimuli, including hot plate, paw flick, and tail pressure when compared to wild type [62]. Interestingly, anesthetized $\mathrm{P} 2 \mathrm{X}^{-/-}$mice demonstrated a deficit in the coding for innocuous warmth as measured using in vivo spinal cord recordings, although mechanical coding remained intact [62]. However, conscious $\mathrm{P}_{2} \mathrm{X}^{--}$animals exhibited an enhanced thermal avoidance behavior, indicating compensatory changes may contribute to the $\mathrm{P} 2 \mathrm{X}^{-/-}$phenotype [105]. Selective knockdown of $\mathrm{P} 2 \mathrm{X} 3$ using intrathecally delivered antisense confirmed many of these findings, showing significant blockade of acute behavior associated with intraplantar injections of $\alpha, \beta$-MeATP and formalin, as well as in models of chronic pain [106, 107]. Furthermore, acute thermal hyperalgesia post-carrageenan with $\mathrm{P} 2 \mathrm{X} 3$ antisense was not different than control which is consistent with findings in experiments with $\mathrm{P} 2 \mathrm{X3}^{-/-}$mice [62]. $\mathrm{P} 2 \mathrm{X} 3$ antisense knockdown also reversed mechanical allodynia in the partial sciatic ligation (PSL) [106] and SNL neuropathic injury models [107]. These findings are particularly interesting, as previous studies demonstrated a significant decrease in P2X3 expression in small diameter neurons in L5-L6 DRG ipsilateral to the site of injury, but an increase in $\mathrm{P} 2 \mathrm{X} 3$ expression in large diameter neurons [108], consistent with findings in sciatic nerve axotomy [71, 82]. Taken together, these data suggest that increased P2X3-receptor activity on large diameter neurons may play a significant role in the transmission of mechanical allodynia associated with nerve injury and neuropathic pain. $\mathrm{P} 2 \mathrm{X}^{-/-}$mice, where $\mathrm{P} 2 \mathrm{X} 3$ homomers are intact and $\mathrm{P} 2 \mathrm{X} 2 / 3$ heteromeric receptors are absent, demonstrate a phenotype distinct from that of the $\mathrm{P} 2 \mathrm{X}^{-/-}$counterparts. For example, intraplantar injection of $\alpha, \beta$-MeATP generated similar nocifensive responses in $\mathrm{P} 2 \mathrm{X} 2^{-/-}$mice compared to wild type, indicating P2X3 homomers are likely responsible for the acute behavior seen with $\alpha, \beta$-MeATP [29]. Of particular interest, $\mathrm{P} 2 \mathrm{X2}^{-/-}$mice exhibited acute flinching behavior similar to that of wild type after formalin injection while the persistent phase was unaffected $[28,29,62]$. These data contrast with $\mathrm{P} 2 \mathrm{X}^{-/-}$animals, with both $\mathrm{P} 2 \mathrm{X} 3$ homomers and $\mathrm{P} 2 \mathrm{X} 2 /$ 3 heteromers absent, which showed a deficit in both the acute and persistent phases. The use of selective knockdown of $\mathrm{P} 2 \mathrm{X} 3$ and $\mathrm{P} 2 \mathrm{X} 2$ subunits suggests that P2X3 homomers have a key role in acute peripheral sensory transmission while $\mathrm{P} 2 \mathrm{X} 2 / 3$ receptors may contribute to the mechanisms that underlie central sensitization. This topic will be explored further in more detail in the next section.

\section{Site of Action of P2X3-Containing Receptor Modulation of Nociceptive Signaling}

Sensory nerves are pseudounipolar, with axons extending from the soma that receive signals from the periphery and relay this information to the central nervous system via central terminals innervating the spinal cord [109]. Immunohistochemical evidence of sensory nerves demonstrate that P2X3-subunits are concentrated in both peripheral and central terminals as well as the cell bodies of the primary sensory afferents $[57,72,75,110,111]$, which place P2X3containing receptors in key locations to initiate and modulate nociceptive activity. 
In the periphery, there are several sources of ATP that could initiate P2X3-mediated signaling. It is estimated that the cytosolic concentration of ATP is approximately 1$10 \mathrm{mM}$ [112]; therefore, large amounts of ATP can be released upon tissue injury. Indeed, in a human incision model, levels of extracellular ATP increased from 0.18 to $14 \mu \mathrm{M} 3-5 \mathrm{~min}$ post injury to the skin [78], concentrations high enough to directly activate P2X3-containing receptors $[7,20]$. Utilizing an in vitro model of tissue injury, lysis of skin cells adjacent to cultured DRG neurons induced depolarizing currents that were abolished with enzymatic degradation of ATP, prior desensitization with ATP, or pharmacologic blockade of P2X receptors [113]. Peripherally, ATP can be released from inflammatory cells via active vesicular release as an "injury" signal [114] that can directly act on P2X3-containing receptors on peripheral nerves thereby initiating a nociceptive response [75, 113]. Synaptic release of ATP has also been studied in peripheral sympathetic nerves. Pioneering work by Geoffrey Burnstock demonstrated that ATP is a cotransmitter with noradrenaline (NA) in sympathetic nerves that innervate guinea pig vas deferens which control vascular tone [115]. Experiments in healthy volunteers demonstrated purinergic antagonists delivered via microdialysis significantly inhibited vasoconstriction induced by whole-body cooling [116]. Primary afferent sensitization can also be subject to modulation via sympathetic efferent activity through P2X3-mediated mechanisms. Recording from single fibers, intraplantar capsaicin enhanced the response of $\mathrm{A} \delta$ - and $\mathrm{C}$-fibers to mechanical stimuli only in animals with intact sympathetic postganglionic efferents [117]. Further experimentation showed that the P2X3-containing receptor antagonist pyridoxal-phosphate-6-azophenyl-2',4'-disulfonic acid (PPADS [21]) could prevent the capsaicin-enhanced mechanical sensitivity in these fibers in sham sympathectomized animals and pretreatment with $\alpha, \beta$-MeATP could restore this sensitivity in sympathectomized rats [118]. In naïve animals, capsaicin-induced sensitization of primary afferents also led to an increase of TRPV1 and calcitonin gene-related peptide (CGRP) expression in sensory neurons, which was not observed in sympathectomized rats. In these sympathectomized rats, the addition of $\alpha, \beta$-MeATP facilitated the capsaicin-induced neuronal upregulation of TRPV1 and CGRP in sensory neurons. Application of uridine triphosphate (UTP), a P2Y-prefering partial agonist, was not effective thereby highlighting the importance of $\mathrm{P} 2 \mathrm{X} 3$-containing receptors in this mechanism of plasticity [119].

In addition to peripheral mechanisms, synaptic release of ATP from the central terminals of primary afferents has a significant role in modulating nociceptive signals in the spinal cord. Evidence supporting presynaptic release of ATP comes from experiments using spinal cord synaptosomes which show elevated levels of ATP upon evoked release [120]. Furthermore, evoked excitatory postsynaptic potentials
(EPSCs) in a transverse spinal cord slice generate a current in lamina II sensitive to suramin, a P2X antagonist [121]. Exogenously applied ATP has been demonstrated to influence glutamate signaling in the spinal cord. When recording from the superficial dorsal horn (substantia gelatinosa), bathapplied ATP elicits fast inward glutamate currents that were inhibited by P2X antagonists [122, 123]. Gu and MacDermott showed that in a DRG-dorsal horn coculture, ATP can increase the frequency of miniature evoked postsynaptic currents (mEPSCs) that were inhibited by NMDA antagonists, indicating an increase in presynaptic glutamate release [124]. Direct application of ATP to isolated dorsal horn neurons did not potentiate glutamate currents, evidence that ATP is likely exerting its effects presynaptically. In a spinal cord slice, application of $\alpha, \beta$-MeATP increased glutamatergic transient activity in lamina II and long-lasting activity in lamina V [73]. Selective ablation of IB4-containing neurons eliminated both the presynaptic P2X3 immunoreactivity in lamina II and the transient $\alpha, \beta$-MeATP-induced signaling while leaving the long-lasting modulation in lamina $\mathrm{V}$ intact, evidence that P2X3-containing receptors are primarily responsible for the modulatory effects of ATP in lamina II [73]. In total, these studies indicate that release of ATP from primary afferent central terminals can act presynaptically on P2X3-containing receptors facilitating glutamate release which could influence nociceptive signaling. Data supporting this hypothesis comes from studies with intrathecal delivery of $\alpha, \beta$-MeATP which caused a dose-dependent increase in thermal hyperalgesia that was blocked by co-administration of PPADS and $2^{\prime}, 3^{\prime}-$ O-(2,4,6-trinitrophenyl) adenosine 5'-triphosphate (TNPATP), a P2X3-containing receptor antagonist [21, 125]. This effect was not seen with the P2X1 preferring agonist $\beta, \gamma$ methylene-L-ATP demonstrating the specific contribution of $\mathrm{P} 2 \mathrm{X} 3$-containing receptors to this effect.

The site of action where $\mathrm{P} 2 \mathrm{X} 3$-containing receptors play a key role in behavioral responses has been evaluated pharmacologically using local administration of antagonists. In the CFA model of inflammatory pain, intraplantar TNP-ATP caused a partial reversal of mechanical hyperalgesia [126]. Spinal, but not intraplantar, administration of A-317491 produced robust reversal of mechanical allodynia in CCI and L5-L6 spinal nerve ligation nerve injury models [127]. Both routes of administration of A-317491 demonstrated efficacy in the acute and persistent phases of the formalin model; however, the reversal of flinching behavior was more robust when dosed intrathecally. In models of inflammation, intraplantar A-317491 elicited a partial dose-dependent reversal of thermal hyperalgesia in the CFA model but was ineffective in acute carrageenan with the same endpoint consistent with earlier reports using antisense $\mathrm{P} 2 \mathrm{X} 3$ and in $\mathrm{P} 2 \mathrm{X}^{-/-}$mice $[62,107]$. Data supporting peripheral P2X3-containing receptors playing a key role in 
mechanical allodynia in chronic inflammation is supported in rat skin-nerve preparations where A-317491 completely blocked mechanical sensitization of C-fibers caused by $\alpha, \beta$-MeATP in CFA-treated skin [54]. In vivo studies using selective antagonists to $\mathrm{P} 2 \mathrm{X} 3$ homomers have also shed light on the specific role of these receptors in nociceptive signaling. Cantin et al. reported that systemically dosed compound $15 \mathrm{~h}$, reportedly $>10$-fold selective for P2X3 homomers over P2X2/3 heteromers, dose-dependently reverses mechanical hyperalgesia $96 \mathrm{~h}$ post-CFA using a mechanical endpoint with free plasma exposures approximately equal to the rat $\mathrm{P} 2 \mathrm{X} 3 \mathrm{IC}_{50}$ at the highest dose tested [90]. In contrast to A-317491, local spinal delivery of compound $15 \mathrm{~h}$ was ineffective in CFA while both compounds were effective when dosed intraplantar [90, 127]. Several notable differences between the studies using compound $15 \mathrm{~h}$ and A-317491 may account for the discrepancies, such as duration postCFA when compounds were tested ( $96 \mathrm{~h}$ vs. $48 \mathrm{~h}$ ), measured endpoints (mechanical allodynia vs. thermal hyperalgesia), and $\mathrm{P} 2 \mathrm{X} 3 / \mathrm{P} 2 \mathrm{X} 2 / 3$ pharmacology ( $>10$ fold selective for $\mathrm{P} 2 \mathrm{X} 3$ homomers vs. non-selective). Assuming local delivery of compound $15 \mathrm{~h}$ achieved concentrations that enabled selective inhibition P2X3 homomers over $\mathrm{P} 2 \mathrm{X} 2 / 3$ heteromers, which was $5 \mathrm{mM}$ at the top dose, peripheral $\mathrm{P} 2 \mathrm{X} 3$ receptors appear to play a primary role over $\mathrm{P} 2 \mathrm{X} 2 / 3$ in mechanical inflammatory pain and efficacy is possible with peripherally restricted compounds. On the other hand, these data also suggest that P2X3 homomers expressed in the central terminals may play a minor role compared to $\mathrm{P} 2 \mathrm{X} 2 / 3$ heteromers in modulating nociceptive signaling due to mechanical inflammatory pain. However, interpreting in vivo results with local delivery of compounds (e.g., intraplantar and intrathecal) is hampered by poor control of compound exposures, therefore potentially engaging other targets important for nociception which can confound interpretations. Experiments with systemically delivered compounds with well understood pharmacokinetics and target pharmacology will be needed to understand if engaging P2X3-containing receptors on central terminals provides added efficacy compared to peripherally restricted compounds. It is also not yet known whether selective inhibition of P2X3 homomers will demonstrate efficacy in preclinical neuropathic pain models as is observed with the non-selective $\mathrm{P} 2 \mathrm{X} 3 / \mathrm{P} 2 \mathrm{X} 2 / 3$ antagonists, or if efficacy with selective inhibition of $\mathrm{P} 2 \mathrm{X} 3$ homomers is limited to inflammatory conditions. Given the low expression of $\mathrm{P} 2 \mathrm{X} 2 / 3$ receptors in primate sensory neurons [77], this is an area where additional investigation is needed as both selective $\mathrm{P} 2 \mathrm{X} 3$ homomer antagonists and nonselective $\mathrm{P} 2 \mathrm{X} 3 / \mathrm{P} 2 \mathrm{X} 2 / 3$ antagonists are in clinical development.

\section{Clinical Programs Investigating P2X3-Containing Receptor Antagonists in Chronic Pain}

Sensory afferents that innervate the urinary bladder originate from the pelvic nerves and primarily consist of $\mathrm{A} \delta$ - and Cfibers, along with sympathetic efferents from the thoracolumbar spinal cord [31], and respond in a graded manner to distension of the bladder [128]. Hydrostatic extension of rabbit bladder induced the release of ATP which occurred in the presence of intraluminal TTX and required an intact epithelial layer, indicating that a non-vesicular mechanism is involved $[129,130]$. The physiologic role of P2X3-containing receptors in this signaling pathway was investigated using $\mathrm{P} 2 \mathrm{X}^{-/-}$ and $\mathrm{P} 2 \mathrm{X}^{-/-}$mice. Immunohistochemical staining in bladder tissue identified P2X3 expression in the subepithelial plexus which was absent in $\mathrm{P} 2 \mathrm{X}^{-/-}$mice while the overall organization of the tissue remained unchanged [28, 131]. Intraluminal ATP release in response to bladder distension of $\mathrm{P} \mathrm{X3}^{-/-}$mice was indistinguishable from wild type [131]; however, pelvic afferents showed an attenuated response to bladder distension indicating P2X3-containing receptors are important for downstream purinergic signaling and not ATP release $[29,131]$. Cystometry studies can measure the repetitive urinary muscle contractions of the micturition reflex in response to slow intravesical infusion of saline. Compared to wild-type animals, both $\mathrm{P} 2 \mathrm{X}^{-/-}$and $\mathrm{P} 2 \mathrm{X}^{-/-}$mice show an increase in the volume of saline required to initiate the reflex, and a decrease in the number of evoked contractions [28, 29]. Local inhibition of P2X3-containing receptors via desensitization with intravesical infusion of $\alpha, \beta$-MeATP [132], or inhibition with the antagonists TNP-ATP or PPADS [131], suppressed bladder afferent activity in response to distension. Spinal administration of the selective $\mathrm{P} 2 \mathrm{X} 3$-containing receptor antagonist AF-792 (formally RO-5) dramatically suppressed bladder contractions to a slow intravesical infusion of saline [91]. Therefore, as in somatosensory nociception, P2X3-containing receptors play a key role in bladder signaling pathways at both a peripheral and spinal level. Evidence supporting a role for P2X3-containing receptors in human bladder pathology comes from studies using tissue isolated from patients. In vitro investigation of bladder urothelial cells (BUCs) from healthy volunteers and patients suffering from interstitial cystitis (IC) demonstrates greater ATP release in response to stretching in IC BUCs [133] which correlated with a significant increase in P2X3 immunoreactivity [134]. Additionally, tissue biopsies taken from patients suffering from intractable detrusor overactivity (DO) demonstrated a significant decrease in PGP9.5(+) P2X3-immunoreactivity after intravesical treatment with botulinum neurotoxin type A (BoNT/A), which correlated with reduction of urgency episodes at 4 and 16 weeks [135]. Although BoNT/A has known effects on presynaptic neurotransmitter release [136], the 
effect on decreasing the number of P2X3-containing sensory fibers and associated downstream purinergic signaling in the bladder may also contribute to the clinical benefit [137, 138]. Based on the evidence supporting a role for P2X3-containing receptors in bladder pathophysiology, a phase 2 a study with gefapixant was initiated in patients suffering from interstitial cystitis/bladder pain syndrome (IC/BPS) [139, 140]. Women aged 18-80 years of age who were diagnosed with IC/BPS for more than 6 months and moderate to severe pain measured by the mean daily Numeric Pain Rating Scale (NPRS) were entered into the study. The trial design was a 4-week doubleblind treatment with 74 female patients (38 placebo and 36 gefapixant). Patients taking gefapixant were dose titrated starting from $50 \mathrm{mg}$ BID and increased $50 \mathrm{mg}$ daily to a maximum dose of $300 \mathrm{mg}$ BID. After the 4-week treatment, gefapixant-treated patients had a decrease in the NPRS score from 6.2 at baseline to 3.3 compared to 6.5 to 4.5 in placebotreated patients $(p=0.019)$. Patients in the treatment arm also had significant improvements in urge to urinate and in both Patient's and Clinician's Global Impression of Change compared to placebo $(p=0.038)$. The most frequent reported adverse event in treated patients was dysgeusia/hypogeusia [139].

Several studies have demonstrated a link between increased levels of ATP in synovial fluid (SF) and joint pain associated with arthritis. For example, SF analyzed from patients diagnosed with osteoarthritis $(\mathrm{OA})$ with knee pain showed elevated levels of ATP compared to SF from patients that had recovered from knee pain [79]. After 5 weeks of treatment with intraarticular injections of the viscosupplement high molecular weight hyaluronic acid (HA), the OA patient group had a significant reduction in SF ATP levels that strongly correlated with a reduction in the Visual Analog Scale (VAS) score [79]. In preclinical studies, elevated SF ATP concentrations were also observed in the stifle joints of dogs with urate-induced synovitis and also in dogs with naturally occurring OA compared to normal joints [80]. In the rat, a subpopulation of $\mathrm{C}$ - and $\mathrm{A} \delta$-fibers that innervate the knee joint demonstrates increased excitation upon intraarticular injection of $\alpha, \beta$-MeATP and ATP which is prevented with coapplication of PPADS [55]. Also in rats, intraarticular coadministration of A-317491 with carrageenan dosedependently prevents the development of hyperalgesia which temporally correlates with lower joint inflammatory cytokine levels and neutrophil infiltration, evidence supporting a role for P2X3-containing receptors in joint pain associated with inflammation [141]. In light of the preclinical evidence and human biology, gefapixant was evaluated in a phase 2 clinical study in patients suffering from pain associated with OA [142, 143]. Patient inclusion criteria included having OA of $\geq 6$ month duration and required baseline average daily pain between 5 and 9 on the Numeric Pain Rating Scale (NPRS). The primary endpoint was change from baseline (week 4) of weekly average daily NPRS. A total of 134 patients completed 4 weeks treatment (gefapixant $n=56$, placebo $n=78$ ). Patients in the gefapixant treatment arm demonstrated a reduction in NRPS over placebo at all time points, with the greatest effects seen at week $2(p=0.04)$. Placebo patients took significantly more rescue medication over all 4 weeks [142]. No serious adverse events were noted, and most common adverse finding in the gefapixant treatment arm was dysgeusia/ hypogeusia.

P2X3 subunit expression is found in vagal sensory neurons that innervate the viscera [144-146] which can transmit mechanosensory signals and nociception [147]. A major source for visceral pain is associated with endometriosis, defined as the presence of functional endometrium outside the uterine cavity which can result in dysmenorrhea, dyspareunia, infertility, and severe pelvic pain [148, 149]. Although the mechanism behind the pain is not clear, biopsies from patients suffering from endometriosis-related pain (ERP) show an increase in the density of sensory nerve fibers innervating the endometriotic lesions [150-152], including those expressing the nociceptive marker CGRP [153]. In endometriotic biopsies, the expression level of $\mathrm{P} 2 \mathrm{X} 3$ was greater in patients compared to age-matched controls and positively correlated with pain severity [76]. Consistent with the human biology data, systemic delivery of an enhanced formulation of A317491 effectively reversed both mechanical and thermal hyperalgesia in a preclinical rodent model of ERP [154]. According to publicly available information, several companies have active clinical programs to test antagonists to P2X3containing receptors in patients suffering from ERP [155, 156].

It is important to note that structurally diverse compounds in clinical development with varying degrees of $\mathrm{P} 2 \mathrm{X} 3 / \mathrm{P} 2 \mathrm{X} 2 / 3$ receptor selectivity have reported alterations in taste that, in some cases, overlap with clinical efficacy $[36,37,139,142]$. Care must be taken to proceed with clinical exposures that minimize the risk for potentially unblinding the patient to treatment, which could inadvertently affect clinical outcomes that use a subjective endpoint like patient-reported outcomes commonly used in pain trials.

\section{Conclusion}

ATP is a key nociceptive modulator, which can act peripherally to heighten the activity of sensitized sensory nerves and centrally to enhance presynaptic glutamate release, thereby potentiating the processes that underlie chronic hypersensitivity. Peripheral and central expressing P2X3-containing receptors play a significant role in these mechanisms, and further clinical exploration may lead to better therapies for the treatment of chronic pain. 
Acknowledgments I would like to thank Jason Uslaner (Neuroscience Department, Merck \& Co., Inc., West Point, PA, USA) and Ian Bell (Department of Discovery Chemistry, Merck \& Co., Inc., West Point, PA, USA) for their time and effort in reviewing this manuscript.

Required Author Forms Disclosure forms provided by the authors are available with the online version of this article.

\section{References}

1. Merskey H, Bogduk N. Classification of chronic pain. 2nd ed Seattle: IASP Press. 1994

2. Institute of Medicine. Relieving Pain in America: A Blueprint for Transforming Prevention, Care, Education, and Research. The National Academies Press; Washington; 2011.

3. Crofford LJ. Chronic Pain: Where the Body Meets the Brain. Trans Am Clin Climatol Assoc. 2015;126:167-83.

4. Cheatle MD, Gallagher RM. Chronic pain and comorbid mood and substance use disorders: a biopsychosocial treatment approach. Curr Psychiatry Rep. 2006;8(5):371-6.

5. Holton FA, Holton P. The possibility that ATP is a transmitter at sensory nerve endings. J Physiol. 1953;119(4):50P-1P.

6. North RA, Surprenant A. Pharmacology of cloned P2X receptors. Annu Rev Pharmacol Toxicol. 2000;40:563-80.

7. Jarvis MF, Khakh BS. ATP-gated P2X cation-channels. Neuropharmacology. 2009;56(1):208-15.

8. Fredholm BB, Abbracchio MP, Burnstock G, Dubyak GR, Harden TK, Jacobson KA, et al. Towards a revised nomenclature for P1 and P2 receptors. Trends Pharmacol Sci. 1997;18(3):79-82.

9. Khakh BS, Burnstock G, Kennedy C, King BF, North RA, Seguela $\mathrm{P}$, et al. International union of pharmacology. XXIV. Current status of the nomenclature and properties of P2X receptors and their subunits. Pharmacol Rev. 2001;53(1):107-18.

10. Alexander SP, Mathie A, Peters JA. Guide to Receptors and Channels (GRAC), 5th edition. Br J Pharmacol. 2011;164 Suppl 1:S1-324.

11. Junger WG. Immune cell regulation by autocrine purinergic signalling. Nat Rev Immunol. 2011;11(3):201-12.

12. Jacobson KA, Muller CE. Medicinal chemistry of adenosine, $\mathrm{P} 2 \mathrm{Y}$ and P2X receptors. Neuropharmacology. 2016;104:31-49.

13. Borea PA, Gessi S, Merighi S, Vincenzi F, Varani K. Pharmacology of Adenosine Receptors: The State of the Art. Physiol Rev. 2018;98(3):1591-625.

14. Egan TM, Cox JA, Voigt MM. Molecular structure of P2X receptors. Curr Top Med Chem. 2004;4(8):821-9.

15. Lewis C, Neidhart S, Holy C, North RA, Buell G, Surprenant A. Coexpression of $\mathrm{P} 2 \mathrm{X} 2$ and $\mathrm{P} 2 \mathrm{X} 3$ receptor subunits can account for ATP-gated currents in sensory neurons. Nature. 1995;377(6548):432-5.

16. Radford KM, Virginio C, Surprenant A, North RA, Kawashima E. Baculovirus expression provides direct evidence for heteromeric assembly of P2X2 and P2X3 receptors. J Neurosci. 1997;17(17): 6529-33.

17. Kowalski M, Hausmann R, Schmid J, Dopychai A, Stephan G, Tang Y, et al. Flexible subunit stoichiometry of functional human P2X2/3 heteromeric receptors. Neuropharmacology. 2015;99: 115-30.

18. Brake AJ, Wagenbach MJ, Julius D. New structural motif for ligand-gated ion channels defined by an ionotropic ATP receptor. Nature. 1994;371(6497):519-23.
19. Mansoor SE, Lu W, Oosterheert W, Shekhar M, Tajkhorshid E, Gouaux E. X-ray structures define human P2X(3) receptor gating cycle and antagonist action. Nature. 2016;538(7623):66-71.

20. Egan TM, Khakh BS. Contribution of calcium ions to P2X channel responses. J Neurosci. 2004;24(13):3413-20.

21. Gum RJ, Wakefield B, Jarvis MF. P2X receptor antagonists for pain management: examination of binding and physicochemical properties. Purinergic Signal. 2012;8(Suppl 1):41-56.

22. Guo A, Vulchanova L, Wang J, Li X, Elde R. Immunocytochemical localization of the vanilloid receptor 1 (VR1): relationship to neuropeptides, the $\mathrm{P} 2 \mathrm{X} 3$ purinoceptor and IB4 binding sites. Eur J Neurosci. 1999;11(3):946-58.

23. Ueno S, Tsuda M, Iwanaga T, Inoue K. Cell type-specific ATPactivated responses in rat dorsal root ganglion neurons. $\mathrm{Br} \mathrm{J}$ Pharmacol. 1999;126(2):429-36.

24. Petruska JC, Cooper BY, Johnson RD, Gu JG. Distribution patterns of different $\mathrm{P} 2 \mathrm{x}$ receptor phenotypes in acutely dissociated dorsal root ganglion neurons of adult rats. Exp Brain Res. 2000;134(1):126-32.

25. Nakatsuka T, Gu JG. ATP P2X receptor-mediated enhancement of glutamate release and evoked EPSCs in dorsal horn neurons of the rat spinal cord. J Neurosci. 2001;21(17):6522-31.

26. Nakatsuka T, Furue H, Yoshimura M, Gu JG. Activation of central terminal vanilloid receptor-1 receptors and alpha betamethylene-ATP-sensitive $\mathrm{P} 2 \mathrm{X}$ receptors reveals a converged synaptic activity onto the deep dorsal horn neurons of the spinal cord. J Neurosci. 2002;22(4):1228-37.

27. Pijacka W, Moraes DJ, Ratcliffe LE, Nightingale AK, Hart EC, da Silva MP, et al. Purinergic receptors in the carotid body as a new drug target for controlling hypertension. Nat Med. 2016;22(10): 1151-9.

28. Cockayne DA, Hamilton SG, Zhu QM, Dunn PM, Zhong Y, Novakovic $\mathrm{S}$, et al. Urinary bladder hyporeflexia and reduced pain-related behaviour in P2X3-deficient mice. Nature. 2000;407(6807):1011-5

29. Cockayne DA, Dunn PM, Zhong Y, Rong W, Hamilton SG, Knight GE, et al. P2X2 knockout mice and P2X2/P2X3 double knockout mice reveal a role for the $\mathrm{P} 2 \mathrm{X} 2$ receptor subunit in mediating multiple sensory effects of ATP. J Physiol. 2005;567(Pt 2):621-39.

30. Ford AP, Gever JR, Nunn PA, Zhong Y, Cefalu JS, Dillon MP, et al. Purinoceptors as therapeutic targets for lower urinary tract dysfunction. Br J Pharmacol. 2006;147 Suppl 2:S132-43.

31. Ford AP, Cockayne DA. ATP and P2X purinoceptors in urinary tract disorders. Handb Exp Pharmacol. 2011(202):485-526.

32. Ferguson AC, Sutton BW, Boone TB, Ford AP, Munoz A. Inhibition of urothelial $\mathrm{P} 2 \mathrm{X} 3$ receptors prevents desensitization of purinergic detrusor contractions in the rat bladder. BJU Int. 2015;116(2):293-301.

33. Salazar BH, Hoffman KA, Zhang C, Zhang YC, Cruz Y, Boone $\mathrm{TB}$, et al. Modulatory effects of intravesical $\mathrm{P} 2 \mathrm{X} 2 / 3$ purinergic receptor inhibition on lower urinary tract electromyographic properties and voiding function of female rats with moderate or severe spinal cord injury. Bju International. 2019;123(3):538-47.

34. Garceau D, Chauret N. BLU-5937: A selective P2X3 antagonist with potent anti-tussive effect and no taste alteration. Pulm Pharmacol Ther. 2019;56:56-62.

35. Pelleg A, Xu F, Zhuang J, Undem B, Burnstock G. DT-0111: a novel drug-candidate for the treatment of COPD and chronic cough. Ther Adv Respir Dis. 2019;13:1753466619877960.

36. Abdulqawi R, Dockry R, Holt K, Layton G, McCarthy BG, Ford $\mathrm{AP}$, et al. P2X3 receptor antagonist (AF-219) in refractory chronic cough: a randomised, double-blind, placebo-controlled phase 2 study. Lancet. 2015;385(9974):1198-205.

37. Niimi A, Ishihara H, Hida H, Miyazaki S. Late Breaking Abstract - Phase 2a randomised, double-blind, placebo-controlled, 
crossover study of a novel P2X3 receptor antagonist S-600918 in patients with refractory chronic cough. European Respiratory Journal. 2019;54(suppl 63):RCT452.

38. Smith JA, Kitt MM, Morice AH, Birring SS, McGarvey LP, Sher MR, et al. Gefapixant, a P2X3 receptor antagonist, for the treatment of refractory or unexplained chronic cough: a randomised, double-blind, controlled, parallel-group, phase $2 \mathrm{~b}$ trial. Lancet Respir Med. 2020.

39. Burnstock G. Purinergic Mechanisms and Pain. Adv Pharmacol. 2016;75:91-137.

40. Bleehen T, Keele CA. Observations on the algogenic actions of adenosine compounds on the human blister base preparation. Pain. 1977;3(4):367-77.

41. Coutts AA, Jorizzo JL, Eady RA, Greaves MW, Burnstock G. Adenosine triphosphate-evoked vascular changes in human skin: mechanism of action. Eur J Pharmacol. 1981;76(4):391-401.

42. Hamilton SG, Warburton J, Bhattacharjee A, Ward J, McMahon SB. ATP in human skin elicits a dose-related pain response which is potentiated under conditions of hyperalgesia. Brain. 2000;123 ( Pt 6):1238-46.

43. Bean BP. Pharmacology and Electrophysiology of Atp-Activated Ion Channels. Trends in Pharmacological Sciences. 1992;13(3): 87-90.

44. Grubb BD, Evans RJ. Characterization of cultured dorsal root ganglion neuron P2X receptors. Eur J Neurosci. 1999;11(1):14954.

45. Petruska JC, Napaporn J, Johnson RD, Gu JG, Cooper BY. Subclassified acutely dissociated cells of rat DRG: histochemistry and patterns of capsaicin-, proton-, and ATP-activated currents. J Neurophysiol. 2000;84(5):2365-79.

46. Virginio C, North RA, Surprenant A. Calcium permeability and block at homomeric and heteromeric $\mathrm{P} 2 \mathrm{X} 2$ and $\mathrm{P} 2 \mathrm{X} 3$ receptors, and P2X receptors in rat nodose neurones. J Physiol. 1998;510 ( Pt 1):27-35.

47. Virginio C, Robertson G, Surprenant A, North RA. Trinitrophenyl-substituted nucleotides are potent antagonists selective for $\mathrm{P} 2 \mathrm{X} 1, \mathrm{P} 2 \mathrm{X} 3$, and heteromeric $\mathrm{P} 2 \mathrm{X} 2 / 3$ receptors. Mol Pharmacol. 1998;53(6):969-73.

48. Undem BJ, Chuaychoo B, Lee MG, Weinreich D, Myers AC, Kollarik M. Subtypes of vagal afferent C-fibres in guinea-pig lungs. J Physiol. 2004;556(Pt 3):905-17.

49. Bland-Ward PA, Humphrey PP. Acute nociception mediated by hindpaw $\mathrm{P} 2 \mathrm{X}$ receptor activation in the rat. Br J Pharmacol. 1997;122(2):365-71.

50. Hamilton SG, McMahon SB, Lewin GR. Selective activation of nociceptors by $\mathrm{P} 2 \mathrm{X}$ receptor agonists in normal and inflamed rat skin. J Physiol. 2001;534(Pt. 2):437-45.

51. Hilliges M, Weidner C, Schmelz M, Schmidt R, Orstavik K, Torebjork E, et al. ATP responses in human C nociceptors. Pain. 2002;98(1-2):59-68.

52. Hamilton SG, Wade A, McMahon SB. The effects of inflammation and inflammatory mediators on nociceptive behaviour induced by ATP analogues in the rat. Br J Pharmacol. 1999;126(1):326-32.

53. Sawynok J, Reid A. Peripheral adenosine 5'-triphosphate enhances nociception in the formalin test via activation of a purinergic p2X receptor. Eur J Pharmacol. 1997;330(2-3):115-21.

54. Wu G, Whiteside GT, Lee G, Nolan S, Niosi M, Pearson MS, et al. A-317491, a selective $\mathrm{P} 2 \mathrm{X} 3 / \mathrm{P} 2 \mathrm{X} 2 / 3$ receptor antagonist, reverses inflammatory mechanical hyperalgesia through action at peripheral receptors in rats. Eur J Pharmacol. 2004;504(1-2):45-53.

55. Dowd E, McQueen DS, Chessell IP, Humphrey PP. P2X receptormediated excitation of nociceptive afferents in the normal and arthritic rat knee joint. Br J Pharmacol. 1998;125(2):341-6.

56. Petruska JC, Cooper BY, Gu JG, Rau KK, Johnson RD. Distribution of $\mathrm{P} 2 \mathrm{X} 1, \mathrm{P} 2 \mathrm{X} 2$, and $\mathrm{P} 2 \mathrm{X} 3$ receptor subunits in rat primary afferents: relation to population markers and specific cell types. J Chem Neuroanat. 2000;20(2):141-62.

57. Vulchanova L, Riedl MS, Shuster SJ, Buell G, Surprenant A, North RA, et al. Immunohistochemical study of the P2X2 and $\mathrm{P} 2 \mathrm{X} 3$ receptor subunits in rat and monkey sensory neurons and their central terminals. Neuropharmacology. 1997;36(9):1229-42.

58. Brederson JD, Jarvis MF. Homomeric and heteromeric P2X3 receptors in peripheral sensory neurons. Curr Opin Investig Drugs. 2008;9(7):716-25.

59. Petruska JC, Mena N, Nakatsuka T, Cooper BY, Johnson RD, Gu JG. P2X1 receptor subunit immunoreactivity and ATP-evoked fast currents in adult rat dorsal root ganglion neurons. Neuroreport. 2000;11(16):3589-92.

60. Kobayashi K, Fukuoka T, Yamanaka H, Dai Y, Obata K, Tokunaga A, et al. Differential expression patterns of mRNAs for P2X receptor subunits in neurochemically characterized dorsal root ganglion neurons in the rat. J Comp Neurol. 2005;481(4): 377-90.

61. Rae MG, Rowan EG, Kennedy C. Pharmacological properties of $\mathrm{P} 2 \mathrm{X} 3$-receptors present in neurones of the rat dorsal root ganglia. Br J Pharmacol. 1998;124(1):176-80.

62. Souslova V, Cesare P, Ding Y, Akopian AN, Stanfa L, Suzuki R, et al. Warm-coding deficits and aberrant inflammatory pain in mice lacking P2X3 receptors. Nature. 2000;407(6807):1015-7.

63. Kowalski M, Hausmann R, Dopychai A, Grohmann M, Franke H, Nieber K, et al. Conformational flexibility of the agonist binding jaw of the human $\mathrm{P} 2 \mathrm{X} 3$ receptor is a prerequisite for channel opening. Br J Pharmacol. 2014;171(22):5093-112.

64. Chen CC, Akopian AN, Sivilotti L, Colquhoun D, Burnstock G, Wood JN. A P2X purinoceptor expressed by a subset of sensory neurons. Nature. 1995;377(6548):428-31.

65. Burnstock G. P2X receptors in sensory neurones. Br J Anaesth. 2000;84(4):476-88.

66. Dussor G, Zylka MJ, Anderson DJ, McCleskey EW. Cutaneous sensory neurons expressing the Mrgprd receptor sense extracellular ATP and are putative nociceptors. J Neurophysiol. 2008;99(4): 1581-9.

67. Dussor G, Koerber HR, Oaklander AL, Rice FL, Molliver DC. Nucleotide signaling and cutaneous mechanisms of pain transduction. Brain Res Rev. 2009;60(1):24-35.

68. Sluka KA, Gregory NS. The dichotomized role for acid sensing ion channels in musculoskeletal pain and inflammation. Neuropharmacology. 2015;94:58-63.

69. Deval E, Lingueglia E. Acid-Sensing Ion Channels and nociception in the peripheral and central nervous systems. Neuropharmacology. 2015;94:49-57.

70. Stephan G, Huang L, Tang Y, Vilotti S, Fabbretti E, Yu Y, et al. The ASIC3/P2X3 cognate receptor is a pain-relevant and ligandgated cationic channel. Nat Commun. 2018;9(1):1354.

71. Bradbury EJ, Burnstock G, McMahon SB. The expression of P2X3 purinoreceptors in sensory neurons: effects of axotomy and glial-derived neurotrophic factor. Mol Cell Neurosci. 1998;12(4-5):256-68.

72. Vulchanova L, Riedl MS, Shuster SJ, Stone LS, Hargreaves KM, Buell G, et al. P2X3 is expressed by DRG neurons that terminate in inner lamina II. Eur J Neurosci. 1998;10(11):3470-8.

73. Nakatsuka T, Tsuzuki K, Ling JX, Sonobe H, Gu JG. Distinct roles of $\mathrm{P} 2 \mathrm{X}$ receptors in modulating glutamate release at different primary sensory synapses in rat spinal cord. J Neurophysiol. 2003;89(6):3243-52.

74. Tsuda M, Koizumi S, Kita A, Shigemoto Y, Ueno S, Inoue K. Mechanical allodynia caused by intraplantar injection of $\mathrm{P} 2 \mathrm{X}$ receptor agonist in rats: involvement of heteromeric $\mathrm{P} 2 \mathrm{X} 2 / 3$ receptor signaling in capsaicin-insensitive primary afferent neurons. J Neurosci. 2000;20(15):RC90. 
75. Cook SP, Vulchanova L, Hargreaves KM, Elde R, McCleskey EW. Distinct ATP receptors on pain-sensing and stretch-sensing neurons. Nature. 1997;387(6632):505-8.

76. Ding S, Zhu L, Tian Y, Zhu T, Huang X, Zhang X. P2X3 receptor involvement in endometriosis pain via ERK signaling pathway. PLoS One. 2017;12(9):e0184647.

77. Serrano A, Mo G, Grant R, Pare M, O'Donnell D, Yu XH, et al. Differential expression and pharmacology of native $\mathrm{P} 2 \mathrm{X}$ receptors in rat and primate sensory neurons. J Neurosci. 2012;32(34): 11890-6.

78. Born GVR, Kratzer MAA. Source and Concentration of Extracellular Adenosine-Triphosphate during Hemostasis in Rats, Rabbits and Man. J Physiol-London. 1984;354(Sep):41929.

79. Kumahashi N, Naitou K, Nishi H, Oae K, Watanabe Y, Kuwata S, et al. Correlation of changes in pain intensity with synovial fluid adenosine triphosphate levels after treatment of patients with osteoarthritis of the knee with high-molecular-weight hyaluronic acid. Knee. 2011;18(3):160-4.

80. Torres BT, Jimenez DA, Budsberg SC. Elevated synovial fluid concentration of adenosine triphosphate in dogs with osteoarthritis or sodium urate-induced synovitis of the stifle. Vet Comp Orthop Traumatol. 2016;29(4):344-6.

81. Novakovic SD, Kassotakis LC, Oglesby IB, Smith JA, Eglen RM, Ford AP, et al. Immunocytochemical localization of P2X3 purinoceptors in sensory neurons in naive rats and following neuropathic injury. Pain. 1999;80(1-2):273-82.

82. Tsuzuki K, Kondo E, Fukuoka T, Yi D, Tsujino H, Sakagami M, et al. Differential regulation of P2X(3) mRNA expression by peripheral nerve injury in intact and injured neurons in the rat sensory ganglia. Pain. 2001;91(3):351-60.

83. Xu GY, Huang LY. Peripheral inflammation sensitizes P2X receptor-mediated responses in rat dorsal root ganglion neurons. J Neurosci. 2002;22(1):93-102.

84. Shinoda M, Ozaki N, Asai H, Nagamine K, Sugiura Y. Changes in $\mathrm{P} 2 \mathrm{X} 3$ receptor expression in the trigeminal ganglion following monoarthritis of the temporomandibular joint in rats. Pain. 2005;116(1-2):42-51.

85. North RA, Jarvis MF. P2X receptors as drug targets. Mol Pharmacol. 2013;83(4):759-69.

86. Marucci G, Dal Ben D, Buccioni M, Marti Navia A, Spinaci A, Volpini R, et al. Update on novel purinergic P2X3 and P2X2/3 receptor antagonists and their potential therapeutic applications. Expert Opin Ther Pat. 2019;29(12):943-63.

87. Jarvis MF, Burgard EC, McGaraughty S, Honore P, Lynch K, Brennan TJ, et al. A-317491, a novel potent and selective nonnucleotide antagonist of $\mathrm{P} 2 \mathrm{X} 3$ and $\mathrm{P} 2 \mathrm{X} 2 / 3$ receptors, reduces chronic inflammatory and neuropathic pain in the rat. Proc Natl Acad Sci U S A. 2002;99(26):17179-84.

88. Carter DS, Alam M, Cai H, Dillon MP, Ford AP, Gever JR, et al. Identification and SAR of novel diaminopyrimidines. Part 1: The discovery of RO-4, a dual $\mathrm{P} 2 \mathrm{X}(3) / \mathrm{P} 2 \mathrm{X}(2 / 3)$ antagonist for the treatment of pain. Bioorg Med Chem Lett. 2009;19(6):1628-31.

89. Richards D, Gever JR, Ford AP, Fountain SJ. Action of MK-7264 (gefapixant) at human $\mathrm{P} 2 \mathrm{X} 3$ and $\mathrm{P} 2 \mathrm{X} 2 / 3$ receptors and in vivo efficacy in models of sensitisation. Br J Pharmacol. 2019;176(13):2279-91

90. Cantin LD, Bayrakdarian M, Buon C, Grazzini E, Hu YJ, Labrecque J, et al. Discovery of P2X3 selective antagonists for the treatment of chronic pain. Bioorg Med Chem Lett. 2012;22(7): 2565-71

91. Kaan TK, Yip PK, Grist J, Cefalu JS, Nunn PA, Ford AP, et al. Endogenous purinergic control of bladder activity via presynaptic $\mathrm{P} 2 \mathrm{X} 3$ and $\mathrm{P} 2 \mathrm{X} 2 / 3$ receptors in the spinal cord. J Neurosci. 2010;30(12):4503-7.
92. Burgey CS. Discovery of $\mathrm{P} 2 \mathrm{X} 3$ receptor antagonists for the treatment of chronic pain. In: 241st ACS national meeting \& exposition, Anaheim, CA, 27-31 March MEDI-15. 2011.

93. Burgey CS. Discovery of the 2nd Generation P2X3 Receptor Antagonist, MK-2548, for the Treatment of Chronic Pain. In: 18th SCI/RSC Medicinal Chemistry Symposium, Cambridge, UK, September 14th, 2015. 2015.

94. Mantyh PW. Bone cancer pain: from mechanism to therapy. Curr Opin Support Palliat Care. 2014;8(2):83-90.

95. Neufeld NJ, Elnahal SM, Alvarez RH. Cancer pain: a review of epidemiology, clinical quality and value impact. Future Oncol. 2017;13(9):833-41.

96. Gilchrist LS, Cain DM, Harding-Rose C, Kov AN, Wendelschafer-Crabb G, Kennedy WR, et al. Re-organization of P2X3 receptor localization on epidermal nerve fibers in a murine model of cancer pain. Brain Res. 2005;1044(2):197-205.

97. Nagamine K, Ozaki N, Shinoda M, Asai H, Nishiguchi H, Mitsudo K, et al. Mechanical allodynia and thermal hyperalgesia induced by experimental squamous cell carcinoma of the lower gingiva in rats. J Pain. 2006;7(9):659-70.

98. Pellegatti P, Raffaghello L, Bianchi G, Piccardi F, Pistoia V, Di Virgilio F. Increased level of extracellular ATP at tumor sites: in vivo imaging with plasma membrane luciferase. PLoS One. 2008;3(7):e2599.

99. Gever JR, Soto R, Henningsen RA, Martin RS, Hackos DH, Panicker S, et al. AF-353, a novel, potent and orally bioavailable P2X3/P2X2/3 receptor antagonist. Br J Pharmacol. 2010;160(6): 1387-98.

100. Medhurst SJ, Walker K, Bowes M, Kidd BL, Glatt M, Muller M, et al. A rat model of bone cancer pain. Pain. 2002;96(1-2):129-40.

101. Kaan TK, Yip PK, Patel S, Davies M, Marchand F, Cockayne DA, et al. Systemic blockade of $\mathrm{P} 2 \mathrm{X} 3$ and $\mathrm{P} 2 \mathrm{X} 2 / 3$ receptors attenuates bone cancer pain behaviour in rats. Brain. 2010;133(9):2549-64.

102. Gonzalez-Rodriguez S, Pevida M, Roques BP, Fournie-Zaluski MC, Hidalgo A, Menendez L, et al. Involvement of enkephalins in the inhibition of osteosarcoma-induced thermal hyperalgesia evoked by the blockade of peripheral P2X3 receptors. Neurosci Lett. 2009;465(3):285-9.

103. Hansen RR, Nasser A, Falk S, Baldvinsson SB, Ohlsson PH, Bahl $\mathrm{JM}$, et al. Chronic administration of the selective P2X3, P2X2/3 receptor antagonist, A-317491, transiently attenuates cancerinduced bone pain in mice. Eur J Pharmacol. 2012;688(1-3):2734.

104. Shcherbatko A, Foletti D, Poulsen K, Strop P, Zhu G, HasaMoreno A, et al. Modulation of P2X3 and P2X2/3 Receptors by Monoclonal Antibodies. J Biol Chem. 2016;291(23):12254-70.

105. Shimizu I, Iida T, Guan Y, Zhao C, Raja SN, Jarvis MF, et al. Enhanced thermal avoidance in mice lacking the ATP receptor P2X3. Pain. 2005;116(1-2):96-108.

106. Barclay J, Patel S, Dorn G, Wotherspoon G, Moffatt S, Eunson L, et al. Functional downregulation of $\mathrm{P} 2 \mathrm{X} 3$ receptor subunit in rat sensory neurons reveals a significant role in chronic neuropathic and inflammatory pain. J Neurosci. 2002;22(18):8139-47.

107. Honore P, Kage K, Mikusa J, Watt AT, Johnston JF, Wyatt JR, et al. Analgesic profile of intrathecal P2X(3) antisense oligonucleotide treatment in chronic inflammatory and neuropathic pain states in rats. Pain. 2002;99(1-2):11-9.

108. Kage K, Niforatos W, Zhu CZ, Lynch KJ, Honore P, Jarvis MF. Alteration of dorsal root ganglion $\mathrm{P} 2 \mathrm{X} 3$ receptor expression and function following spinal nerve ligation in the rat. Exp Brain Res. 2002;147(4):511-9.

109. Kandel ER, Schwartz J, Mack TMJ. Principles of Neural Science (4th ed.). Cambridge: McGrawHill. 2000.

110. Llewellyn-Smith IJ, Burnstock G. Ultrastructural localization of P2X3 receptors in rat sensory neurons. Neuroreport. 1998:9(11): 2545-50. 
111. Burgard EC, Niforatos W, van Biesen T, Lynch KJ, Touma E, Metzger RE, et al. P2X receptor-mediated ionic currents in dorsal root ganglion neurons. J Neurophysiol. 1999;82(3):1590-8.

112. Beis I, Newsholme EA. The contents of adenine nucleotides, phosphagens and some glycolytic intermediates in resting muscles from vertebrates and invertebrates. Biochem J. 1975;152(1):2332.

113. Cook SP, McCleskey EW. Cell damage excites nociceptors through release of cytosolic ATP. Pain. 2002;95(1-2):41-7.

114. Kato Y, Hiasa M, Ichikawa R, Hasuzawa N, Kadowaki A, Iwatsuki $\mathrm{K}$, et al. Identification of a vesicular ATP release inhibitor for the treatment of neuropathic and inflammatory pain. Proc Natl Acad Sci U S A. 2017;114(31):E6297-E305.

115. Burnstock G. Noradrenaline and ATP as cotransmitters in sympathetic nerves. Neurochem Int. 1990;17(2):357-68.

116. Lang JA, Krajek AC, Smaller KA. Evidence for a functional vasoconstrictor role for ATP in the human cutaneous microvasculature. Exp Physiol. 2017;102(6):684-93.

117. Ren Y, Zou X, Fang L, Lin Q. Sympathetic modulation of activity in Adelta- and C-primary nociceptive afferents after intradermal injection of capsaicin in rats. J Neurophysiol. 2005;93(1):365-77.

118. Ren Y, Zou X, Fang L, Lin Q. Involvement of peripheral purinoceptors in sympathetic modulation of capsaicin-induced sensitization of primary afferent fibers. J Neurophysiol. 2006;96(5):2207-16.

119. Xu X, Wang P, Zou X, Li D, Fang L, Gong K, et al. The effects of sympathetic outflow on upregulation of vanilloid receptors TRPV(1) in primary afferent neurons evoked by intradermal capsaicin. Exp Neurol. 2010;222(1):93-107.

120. Sawynok J, Downie JW, Reid AR, Cahill CM, White TD. ATP release from dorsal spinal cord synaptosomes: characterization and neuronal origin. Brain Res. 1993;610(1):32-8.

121. Bardoni R, Goldstein PA, Lee CJ, Gu JG, MacDermott AB. ATP $\mathrm{P} 2 \mathrm{X}$ receptors mediate fast synaptic transmission in the dorsal horn of the rat spinal cord. J Neurosci. 1997;17(14):5297-304.

122. Li J, Perl ER. ATP modulation of synaptic transmission in the spinal substantia gelatinosa. J Neurosci. 1995;15(5 Pt 1):3357-65.

123. Li P, Calejesan AA, Zhuo M. ATP P2x receptors and sensory synaptic transmission between primary afferent fibers and spinal dorsal horn neurons in rats. J Neurophysiol. 1998;80(6):3356-60.

124. Gu JG, MacDermott AB. Activation of ATP P2X receptors elicits glutamate release from sensory neuron synapses. Nature. 1997;389(6652):749-53.

125. Tsuda $\mathrm{M}$, Ueno $\mathrm{S}$, Inoue $\mathrm{K}$. In vivo pathway of thermal hyperalgesia by intrathecal administration of alpha,beta-methylene ATP in mouse spinal cord: involvement of the glutamateNMDA receptor system. Br J Pharmacol. 1999;127(2):449-56.

126. Dai Y, Fukuoka T, Wang H, Yamanaka H, Obata K, Tokunaga A, et al. Contribution of sensitized $\mathrm{P} 2 \mathrm{X}$ receptors in inflamed tissue to the mechanical hypersensitivity revealed by phosphorylated ERK in DRG neurons. Pain. 2004;108(3):258-66.

127. McGaraughty S, Wismer CT, Zhu CZ, Mikusa J, Honore P, Chu $\mathrm{KL}$, et al. Effects of A-317491, a novel and selective P2X3/P2X2/ 3 receptor antagonist, on neuropathic, inflammatory and chemogenic nociception following intrathecal and intraplantar administration. Br J Pharmacol. 2003;140(8):1381-8.

128. Janig W, Morrison JF. Functional properties of spinal visceral afferents supplying abdominal and pelvic organs, with special emphasis on visceral nociception. Prog Brain Res. 1986;67:87114.

129. Ferguson DR, Kennedy I, Burton TJ. ATP is released from rabbit urinary bladder epithelial cells by hydrostatic pressure changes-a possible sensory mechanism? J Physiol. 1997;505 ( Pt 2):503-11.

130. Burnstock G. Release of vasoactive substances from endothelial cells by shear stress and purinergic mechanosensory transduction. J Anat. 1999;194 ( Pt 3):335-42.
131. Vlaskovska M, Kasakov L, Rong W, Bodin P, Bardini M, Cockayne DA, et al. P2X3 knock-out mice reveal a major sensory role for urothelially released ATP. J Neurosci. 2001;21(15):56707.

132. Namasivayam S, Eardley I, Morrison JF. Purinergic sensory neurotransmission in the urinary bladder: an in vitro study in the rat. BJU Int. 1999;84(7):854-60.

133. Sun Y, Chai TC. Augmented extracellular ATP signaling in bladder urothelial cells from patients with interstitial cystitis. Am J Physiol-Cell Ph. 2006;290(1):C27-C34.

134. Sun $\mathrm{Y}$, Chai TC. Up-regulation of $\mathrm{P} 2 \mathrm{X} 3$ receptor during stretch of bladder urothelial cells from patients with interstitial cystitis. J Urol. 2004;171(1):448-52.

135. Apostolidis A, Popat R, Yiangou Y, Cockayne D, Ford AP, Davis JB, et al. Decreased sensory receptors P2X3 and TRPV1 in suburothelial nerve fibers following intradetrusor injections of botulinum toxin for human detrusor overactivity. J Urol. 2005;174(3):977-82; discussion 82-3.

136. Abbruzzese G, Berardelli A. Neurophysiological effects of botulinum toxin type A. Neurotox Res. 2006;9(2-3):109-14.

137. Sahai A, Khan MS, Gregson N, Smith K, Dasgupta P, Group GKTBS. Botulinum toxin for detrusor overactivity and symptoms of overactive bladder: where we are now and where we are going. Nat Clin Pract Urol. 2007;4(7):379-86.

138. Lawrence GW, Aoki KR, Dolly JO. Excitatory cholinergic and purinergic signaling in bladder are equally susceptible to botulinum neurotoxin a consistent with co-release of transmitters from efferent fibers. J Pharmacol Exp Ther. 2010;334(3):1080-6.

139. Moldwin R KM, Mangel J, Beyer R, Hanno P, Buterra P, Ford A. A PHASE 2 STUDY IN WOMEN WITH INTERSTITIAL CYSTITIS/BLADDER PAIN SYNDROME (IC/BPS) OF THE NOVEL P2X3 ANTAGONIST AF-219. [abstract No 23] In: 45th International Continence Society (ICS) Annual Meeting; 2015 Oct 6-9; Montreal, Canada Bristol (United Kingdom). 2015.

140. NCT01569438 Available from: https:/clinicaltrials.gov/. Accessed 6 May 2020.

141. Teixeira JM, Bobinski F, Parada CA, Sluka KA, Tambeli CH. P2X3 and P2X2/3 Receptors Play a Crucial Role in Articular Hyperalgesia Development Through Inflammatory Mechanisms in the Knee Joint Experimental Synovitis. Mol Neurobiol. 2017;54(8):6174-86.

142. Strand V KM, Kivitz A, Ford A, Butera P, McCarthy B. An Exploratory 4-Week Study of a P2X3 Antagonist AF-219 in the Treatment of Patients with Osteoarthritis (OA) of the Knee. ACR/ ARHP Annual Meeting, Abstract 2240. 2014.

143. NCT01554579 Available from: https://clinicaltrials.gov. Accessed 6 May 2020.

144. Papka RE, Hafemeister J, Storey-Workley M. P2X receptors in the rat uterine cervix, lumbosacral dorsal root ganglia, and spinal cord during pregnancy. Cell Tissue Res. 2005;321(1):35-44.

145. Chaban VV. Visceral sensory neurons that innervate both uterus and colon express nociceptive TRPv1 and $\mathrm{P} 2 \mathrm{X} 3$ receptors in rats. Ethn Dis. 2008;18(2 Suppl 2):S2-20-4.

146. Kollarik M, Ru F, Undem BJ. Phenotypic distinctions between the nodose and jugular TRPV1-positive vagal sensory neurons in the cynomolgus monkey. Neuroreport. 2019;30(8):533-7.

147. Burnstock G. Purinergic mechanosensory transduction and visceral pain. Mol Pain. 2009;5:69.

148. Strathy JH, Molgaard CA, Coulam CB, Melton LJ, 3rd. Endometriosis and infertility: a laparoscopic study of endometriosis among fertile and infertile women. Fertil Steril. 1982;38(6): 667-72.

149. Bloski T, Pierson R. Endometriosis and Chronic Pelvic Pain: Unraveling the Mystery Behind this Complex Condition. Nurs Womens Health. 2008;12(5):382-95. 
150. Wang G, Tokushige N, Markham R, Fraser IS. Rich innervation of deep infiltrating endometriosis. Hum Reprod. 2009;24(4):827-34.

151. Zhang $\mathrm{X}, \mathrm{Lu} \mathrm{B}$, Huang $\mathrm{X}, \mathrm{Xu} \mathrm{H}$, Zhou C, Lin J. Innervation of endometrium and myometrium in women with painful adenomyosis and uterine fibroids. Fertil Steril. 2010;94(2):730-7.

152. Arnold J, Barcena de Arellano ML, Ruster C, Vercellino GF, Chiantera V, Schneider A, et al. Imbalance between sympathetic and sensory innervation in peritoneal endometriosis. Brain Behav Immun. 2012;26(1):132-41.

153. Barcena de Arellano ML, Munch S, Arnold J, Helbig S, Schneider A, Mechsner S. Calcium-binding protein expression in peritoneal endometriosis-associated nerve fibres. Eur J Pain. 2013;17(10): 1425-37.
154. Yuan M, Ding S, Meng T, Lu B, Shao S, Zhang X, et al. Effect of A-317491 delivered by glycolipid-like polymer micelles on endometriosis pain. Int J Nanomedicine. 2017;12:8171-83.

155. NCT03654326 Available from: https://clinicaltrials.gov/. Accessed 6 May 2020.

156. Available from: https://pharma.bayer.com/p2x3-antagonists. Accessed 6 May 2020.

Publisher's Note Springer Nature remains neutral with regard to jurisdictional claims in published maps and institutional affiliations. 